\title{
ANÁLISIS DE LA PUESTA EN IMAGEN DEL TELEDRAMA
}

\author{
Rafael Cremades Salvador \\ Doctor por la Universidad Complutense
}

\begin{abstract}
Resumen
Se propone un modelo para el estudio de la puesta en imagen de los discursos teatrales adaptados para televisión. Una vez aclarados los conceptos de teledrama y de puesta en imagen relacionada con la puesta en escena puramente teatral, se iniciará el análisis a través de los cinco elementos fundamentales: personajes, espacio, tiempo, acción y la propia imagen audiovisual televisiva.
\end{abstract}

\section{Palabras clave}

Análisis - Puesta en imagen - Discurso teatral - Televisión - Personajes - Espacio - Tiempo Acción - Imagen audiovisual - Teledrama.

\begin{abstract}
A model is proposed to analyse the adaptation of theatre speeches on television. Once teledrama concepts have been explained and how it is performed on television related to the purely theatre staging, the analysis begins using the most important elements: characters, space, time, action and the own audiovisual television image.
\end{abstract}

\section{Key words}

Analysis - Television Performance - Theatre Speech - Television - Characters - Space Time Action - Audiovisual Image - Teledrama. 


\section{Introducción}

Desde estas páginas se desea contribuir a resucitar ese cadáver de las adaptaciones al medio técnico audiovisual de obras teatrales.

Al iniciar este trabajo surge la presunta necesidad de aclarar, sobre todo, dos conceptos: el teledrama y la puesta en imagen.

El afán de abortar en televisión el vocablo teatro, como uno de sus géneros, obliga a buscar una denominación que signifique el producto televisivo basado en un texto dramático teatral.

Cada medio tiene su lenguaje específico y cualquier cambio de soporte precisa la adaptación del texto -una transducción- porque el proceso de comunicación en cada caso es diferente. Obviar esto parece una falta de respeto y -en ocasiones- hasta una aberración. El discurso audiovisual suele respetar, en su significante, el significado deseado por el autor del texto teatral originario. Incluso, se deben respetar, en el texto dialógico del guión literario del teledrama, construcciones, giros, léxico, etc., propios del autor de la obra teatral.

Así pues, el realizador -que suele ser el adaptador- trata de respetar-aunque relativamente, dadas las características del medio televisión frente al teatral- el paratexto, es decir, las acotaciones (descripción de decorados, mobiliario, vestuario, aspecto exterior del comediante, etc.) y didascalias (sugerencias al actor y al director para la interpretación y la puesta en escena). Hay que tener en cuenta que una puesta sobre escenario no es lo mismo que la puesta en escena e imagen del teledrama. La aportación del realizador en cuanto a los elementos propios de la imagen (escala de planos, su articulación, encuadre, angulación, profundidad de campo, etc.) es importante y no figura en el texto literario originario.

Cuando se adapta una obra de teatro para la televisión, es conveniente no perder de vista las características del telefilm. Su planteamiento temporal debe ser más breve que en teatro, y el total ha de aproximarse -salvo necesarias excepciones- al módulo de una hora y quince minutos, sin incluir los bloques publicitarios. Generalmente se reduce el tiempo de la representación por estar en juego el difícil mantenimiento de la atención del telespectador y para evitar su fatiga. A partir de aquí los responsables de la empresa pueden mantener contacto con los realizadores con objeto de determinar la posibilidad o no de acortar al mínimo eficaz la duración de los teledramas (salvo retransmisiones y desarrollo en tiempo real). En algunas ocasiones será factible y en otras no. En los casos negativos, la empresa podría incluso plantearse el cambio de obra.

Se eliminan escenas de relleno y se evitan algunas redundancias con objeto de evitar al telespectador cierta lentitud, que sobrelleva mejor el espectador teatral. A veces procede la 
actualización de algunos lexemas y expresiones. También será preciso evitar o acortar los parlamentos, que pueden sustituirse por acciones escénicas que la cámara enfatice. Los diálogos se harán concisos y se acortarán las escenas. Utilizando el zoom, las cámaras destacarán acercamientos o planos detalle de todos aquellos elementos de decorado, acción o atrezzo que sean importantes en la diégesis, como puertas, reacciones de personajes, armas, etc., evitando hacerlo con comentarios o alusiones de los actores.

El número de personajes será reducido. Por ejemplo, cinco comediantes al mismo tiempo se perderían en un plano general. Esto nos obliga a renunciar a textos con excesivo número de integrantes en acción, o de excesiva duración, o con un desmedido decorado, o abundantes acciones no esenciales para la línea dramática principal. Esto puede obligar a la eliminación de personajes episódicos o al recurso de la revelación oral para informar al espectador de algunos hechos ocurridos fuera de campo.

La proximidad de la cara del actor -que la cámara enfatiza o distingue- tiene más fuerza que ciertos parlamentos teatrales, escritos para la expresión de interés, sorpresa, alegría, etc., de los personajes. Hay diálogos que suenan bien en teatro pero que, por la proximidad de los personajes, pueden oírse falsos en televisión. El adaptador ha de cuidar, más que en el original teatral, que el guión televisivo posea su lenguaje específico y un desarrollo de la acción claro, sencillo y preciso.

Se considera inadecuada la fórmula teatro -con prefijo, sin él o con complemento- para cualquier producto televisivo. Si se trata de televisión resulta incongruente hablar de teatro, salvo para agregar la expresión "basado en la obra teatral homónima de...”. Así se ha hecho, por ejemplo, cuando el origen ha sido una novela, como Cañas y barro, La barraca, Fortunata y Jacinta, La Regenta, Los gozos y las sombras, y otras.

En cuanto al título del programa es preciso olvidarse de denominaciones como: Teatro, Teleteatro, El teatro de siempre, Teatro breve... Nos parecen aceptables cualesquiera de los ya utilizados sin el vocablo teatro: Primera función, Butaca de salón, Sesión de noche... y, sobre todo, Estudio 1, que también podría ser 2, 3, 4 ó $5 \ldots$

Se entiende como teledrama el producto televisivo cuyos guiones, literario y técnico, se basan en un texto específicamente teatral, convenientemente adaptado al medio televisión y grabado con sus facilidades.

Dicho esto, se precisa que el teledrama es un género televisivo con vocación de ser realizado, fundamentalmente, en estudio. 
Las grabaciones en escenarios teatrales o naturales, sin previa adaptación, resultan productos impropios y sólo pueden considerarse retransmisiones, no teledramas. En ellas, creación y comunicación pueden ser simultáneas o no, pero la primera se está produciendo en un medio (teatro) y la comunicación en otro (televisión). La figurativización y estructuración de unos sistemas de signos que crean un sentido depende del medio de comunicación elegido y en modo alguno podemos crear teatro y emitirlo por televisión si antes no se ha adaptado $\mathrm{y}$, por tanto, convertido en un producto televisivo. Ubersfeld $(1997 ; 28)$ dice que "las fotos y los vídeos no son más que herramientas imperfectas en las que se pierden las propias condiciones de la comunicación teatral y la respuesta del receptor".

La grabación de una obra de teatro (salvo grandes espectáculos), en un escenario o exteriores, y su exhibición a través del medio televisivo podría calificarse de aberración. La difusión por TV de un espectáculo teatral se convierte en una pálida aproximación a la representación directa en un escenario y se deteriora. Los elementos tridimensionales pierden la profundidad, el espacio global se recorta ofreciendo fragmentos y no detalles ${ }^{1}$, desaparece la fuerza de los espacios en off, los movimientos internos se distorsionan y se hacen menos perceptibles, se dificulta la apreciación de la proxémica, se pierde -en demasiadas ocasiones- el fondo, se reduce la gama musical, la voz se desnaturaliza, se aborta la influencia del telespectador en el espectáculo, etc. Se admiten las retransmisiones de todos aquellos espectáculos en grandes escenarios de complicada o ineficaz adaptación. En ese caso se encontrarían la ópera, el ballet, las funciones al aire libre -como las producidas por grupos como Els Comediants- los acontecimientos deportivos, las corridas de toros, etc.

En cuanto a la puesta en imagen, se trataría de la puesta en escena televisiva, es decir, el concepto de puesta en escena teatral a la que se agregan los elementos específicos del medio televisivo.

\footnotetext{
${ }^{1}$ La diferencia entre detalle y fragmento está clarificada por Omar Calabrese (1994; 86-89). Así como el detalle es concomitante con el entero, en el fragmento, ese espacio total está in absentia. El detalle se percibe a partir del completo y se ve siempre como integrado en ese espacio global que nunca se pierde. Por ejemplo, mediante el zoom o el travelling llegamos al detalle desde el entero. No sucede así con el fragmento, cuyos límites son interrumpidos hasta considerarlo aislado. Si los límites del detalle llaman a la re-constitución, en el fragmento obligan a la "reconstrucción. El fragmento es explicado. El detalle explica de manera nueva el sistema mismo”.
} 
Son componentes de la puesta en escena los relativos a las cuatro primeras unidades básicas: personajes, espacio, tiempo y acción. En el sistema de la imagen visual y auditiva entran en la puesta en escena el movimiento interno, el cromatismo, la textura, la música y los efectos. El movimiento escénico es, quizá, el elemento más determinante de la puesta en escena.

En la fase de la puesta en imagen se inserta el inventario de planos, su escala y su articulación, el encuadre, la angulación, la acción en campo o fuera de él, los movimientos de cámara, la profundidad de campo, la colocación de los espacios bisagra ( bloques publicitarios y créditos) y los efectos visuales.

En la producción de un teledrama se dan las dos fases.

La televisión es lenguaje -como dice Eco- dotado de una tercera articulación. Esta nueva articulación aparece cuando el signo, que ha pasado por las dos articulaciones del texto literario, recibe otro significado específico de la imagen televisiva que refuerza la intencionalidad de los autores. Este lenguaje específico televisivo está en posesión de todo receptor, aun cuando no sea consciente de ello. El telespectador medio distingue conceptos como montaje (o edición), iluminación, escala de planos, primer plano, encuadre, profundidad de campo, secuencia, escena, bloque, flash-back, etc.

El teledrama, en su principio, es literatura, aunque con vocación de puesta en imagen. Es, pues, el conjunto de actos de lenguaje (no sólo de lengua) que se resuelven en una combinación de unidades sintácticas de todo tipo (texto expresado, música, lenguaje cinésico y proxémico, espacio, tratamiento de la imagen, tiempo, etc.), y que convierten el enunciado en enunciación. Al mostrar unas imágenes audiovisuales reforzadas con la prosodia, con la expresión corporal, el aspecto exterior, y la acción del comediante, dentro de un espacio escenográfico, en un tiempo y con una iluminación y un tratamiento de imágenes específico, la literatura se hace viva y hasta las cosas dicen.

Los signos escénicos poseen una doble función significativa: caracterizadora y funcional. Determinado salón puede caracterizar a una familia acomodada, pero a la vez, es un espacio para recibir, leer, conversar... vivir. Un lujoso sillón puede ser trono de Enrique IV y, a la vez, un mueble para sentarse y descansar. Una vajilla de aluminio caracteriza a una familia pobre y una de porcelana a unos personajes acomodados, pero ambas sirven para comer. Una luz azulada puede caracterizar la noche y ser atmósfera adecuada para el asesinato. 
En el teledrama se dan las dos funciones primarias: expresión y comunicación. Con la primera se exteriorizan pensamientos y sentimientos provocando, a través de la función comunicativa, representaciones, y suscitando emociones en el telespectador.

Tomando como referencia los elementos dramáticos teatrales de Kowzan $(1992 ; 189)$ se ofrece la Tabla 1 aplicada al teledrama:

\section{Tabla 1}

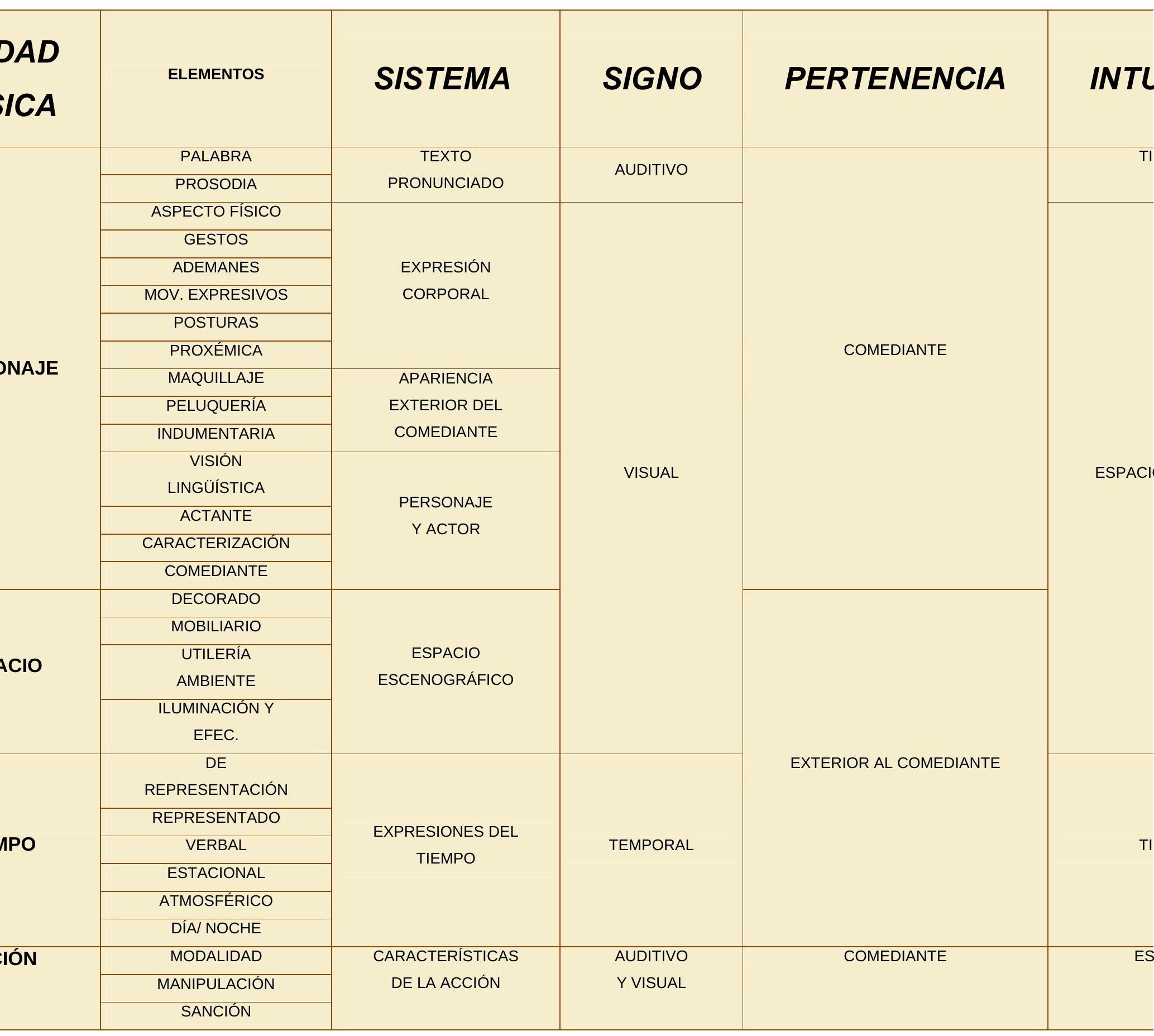




\begin{tabular}{|c|c|c|c|c|c|}
\hline & CONFLICTOS & & & & \\
\hline & INTRIGAS & & & & \\
\hline \multirow{13}{*}{$\begin{array}{l}\text { SEN } \\
\text { AL Y } \\
T I V A\end{array}$} & ENCUADRE & \multirow{13}{*}{$\begin{array}{c}\text { PUESTA EN } \\
\text { IMAGEN VISUAL Y } \\
\text { AUDITIVA }\end{array}$} & \multirow{13}{*}{$\begin{array}{l}\text { VISUAL Y } \\
\text { AUDITIVO }\end{array}$} & \multirow{13}{*}{$\begin{array}{c}\text { DENTRO Y FUERA DEL } \\
\text { COMEDIANTE }\end{array}$} & \\
\hline & ESCALA PLANOS & & & & \\
\hline & ARTICULACIÓN & & & & \\
\hline & ANGULACIÓN & & & & \\
\hline & PROFUND. DE & & & & \\
\hline & CAMPO & & & & \\
\hline & MOV. DE CÁMARA & & & & \\
\hline & MOV. INTERNO & & & & \\
\hline & CROMATISMO & & & & \\
\hline & TEXTURA & & & & \\
\hline & CAMPO & & & & \\
\hline & MÚSICA Y & & & & \\
\hline & EFECTOS & & & & \\
\hline
\end{tabular}

\section{Objetivos}

Los principales objetivos son:

a) Configurar un modelo de análisis del discurso teatral adaptado a televisión.

b) Posibilitar -a través del mismo- el estudio comparativo de las diversas unidades analizadas, tanto en el eje sintagmático -in praesencia- como en el paradigmático -in absentia. Es decir, redundancias necesarias, isotopías, etc., en el mismo teledrama, o relaciones entre elementos pertenecientes al mismo autor (del texto teatral literario, del realizador del teledrama) dentro del género correspondiente (tragedia, comedia cómica, comedia dramática, etc.) o entre los diversos géneros, diferentes épocas, etc.

c) Establecer diferencias con el discurso teatral originario.

d) Evidenciar que el punto de vista idóneo para este estudio es el del receptor del mensaje, subrayando el carácter pragmático del trabajo.

e) Demostrar la facilidad de hibridación del teatro y de la televisión.

\section{Metodología}

De acuerdo con la afirmación del profesor Vidal-Beneyto hecha pública en la presentación del programa Europa Mundi en Santiago de Compostela en el año 2000, "Nada hay más práctico que una buena teoría”. La metodología de este trabajo posee los rasgos característicos del carácter 
científico: es teórica, tanto en su origen como en su fin. Presenta, además, unas conclusiones eminentemente prácticas en las que interactúan lo teórico y la experiencia.

La toma de datos del teledrama y el tratamiento efectivo que reciben son los componentes de esta investigación. La fidelidad al principio empírico se materializa en una descripción coherente, exhaustiva y tan simple como ha sido posible. Lo más importante es la ausencia de contradicciones; luego, la exhaustividad; y después, la simplicidad. El modelo ha nacido con el estudio de las unidades básicas presentes en la puesta en imagen de una obra de teatro adaptada para su producción y difusión a través de la televisión. Todas se han analizado desde los puntos de vista cuantitativo y cualitativo, partiendo de una valoración pormenorizada de cada una y llegando a la consideración de la obra completa.

El método puede calificarse como inductivo-deductivo. La inducción conduce de lo particular a lo general, comprendiendo la obtención de los datos. La deducción viene identificada por su clasificación, su enfrentamiento con las ideas teóricas concomitantes, y la consecución de las conclusiones.

La metodología sigue -como todo desarrollo científico- la doble vía analítico-sintética. Primero distingue y segmenta los elementos de la realidad para después -en el análisisrecomponer, con objeto de lograr una visión estructural.

Es un procedimiento selectivo que concentra su análisis en los elementos pertinentes, tratando de trascender esas apariencias que tienen tanta importancia en los espectaculares medios que nos ocupan. Es útil prescindir de lo accidental yendo a lo esencial, a lo trascendido, para evitar errores de accidente.

Las fuentes para la realización son mixtas. Las primarias son la cinta de vídeo o el DVD correspondiente al teledrama. Como fuentes secundarias se utilizan los textos teatrales originarios y -si es posible- los guiones literario y técnico del teledrama y el cuaderno del realizador. 


\section{Artículo}

El texto dramático - dentro del plano de la expresión- distingue los planos textual y escénico. El primero comprende el cuerpo literario y contiene dos categorías: texto dialogado y para-texto; el escénico contiene la puesta en escena y la puesta en imagen.

Este modelo de análisis se inscribe en el plano escénico y considera -por ejemplo en el personaje- los datos cuantitativos que subrayan la determinación de su importancia, así como la prosodia, la expresión corporal, la apariencia externa, su caracterización y las relaciones con el resto de las dramatis personae, más que un estudio de la lengua del texto escrito.

El análisis del teledrama considera el de sus cinco sistemas básicos: personajes, espacio, tiempo, acción y tratamiento de las imágenes visual y auditiva, encuadrados en los planos de coherencia semántica y en los del significado.

Consideramos como planos de coherencia semántica: el plano elemental, el intermedio y el textual.

El plano elemental comprende las unidades mínimas con significado. Generalmente son las escenas.

El plano intermedio integra los elementos contemplados en el plano elemental en unidades de coherencia mayores como las situaciones, los cuadros o los actos.

En el plano textual se llega al análisis del discurso completo.

Los signos en un proceso de comunicación -como el teledrama- producen significado en los planos del objeto, del sujeto y de la inter-subjetividad.

En el plano del objeto, si un signo acompaña al habla crea significado. Condiciona y define -sobre todo- el contexto y el significado de los signos lingüísticos; realza el signo verbal y potencia el significado de los signos prosódicos como, por ejemplo, la entonación o el acento (un acento irónico se potencia con una ligera sonrisa). Los signos cinésicos que sustituyen al habla son indicadores, si se refieren a personas y objetos presentes o al espacio; icónicos, si aluden a una característica elegida al azar; simbólicos, si la relación significante/significado se basa en la convención.

En el plano del sujeto se relacionan con el personaje respectivo. Expresan: edad, sexo, status social, nivel cultural, profesión, complexión física, estado anímico, rasgos característicos, emociones, sentimientos y otras circunstancias. Los cinésicos pueden ser, por ejemplo, defectos 
físicos, gestos infantiles, gestos característicos del hombre o de la mujer, gestos propios de un rol determinado, gestos soeces, gestos del beodo, etc.

En el plano de la inter-subjetividad tienen que ver con las relaciones entre las dramatis personce. Actúan la mayor parte de las veces junto a signos lingüísticos y regulan el proceso de interacción.

La sucesión de los signos en el escenario requiere una segmentación horizontal sin olvidar que la simultaneidad de signos acústicos y visuales por unidad de tiempo en medios audiovisuales, como la televisión, exige la segmentación vertical. La primera permite analizar las relaciones sintagmáticas entre unidades de un mismo sistema y con la segmentación vertical se aprecian las relaciones paradigmáticas entre elementos de diversos sistemas.

Interesa el análisis de los componentes de cada uno de los sistemas y el estudio comparado de todos ellos. Después, al contrastar resultados, se obtendrán las conclusiones correspondientes, por géneros, autores, etc. Igualmente se trabajaría con unidades menores como decorado, mobiliario, iluminación, etc.

El elemento primario del lenguaje teatral o del teledrama es el comediante. De lo que no se puede prescindir en estos lenguajes es del ser humano en su doble rol de actor-personaje y de espectador.

El comediante que interpreta al personaje más que hablar, dice, y enriquece un texto rigurosamente literario con una adecuada prosodia en la que entran, como recursos importantes, las pausas y los silencios. De manera que hay una voz, pero también un silencio que -aunque no se oiga- se "escucha" y se siente. Además, el actor subraya y redunda con gestos, ademanes, posturas, proxémica y movimientos expresivos. Su caracterización -que no sólo es física- se completa con maquillaje, peluquería e indumentaria. La ausencia de muchos de los elementos citados también le identifica.

Se puede definir el espacio como una forma articulada desde la extensión para darle una cierta significación. Es como la extensión en la que se sitúan cuerpos y objetos. Articulado y construido por el sujeto, el espacio -que no la extensión- está íntimamente relacionado con él.

En el teledrama, y desde el punto vista del telespectador, no se llega jamás al espacio orgánico $^{2}$. Se mueve en un espacio perceptivo ${ }^{3}$.

\footnotetext{
${ }^{2}$ Es el espacio de la acción.
} 
Por lo que se refiere al tiempo, los comediantes y los espectadores teatrales confluyen en el presente, mientras que en el teledrama lo hacen en pasado. Es un elemento manipulado y manipulable en cuanto a sucesión o simultaneidad de acción.

El ser humano es acción expresada en el discurso, y la expresión -oral, escrita, cinésica, musical y demás- es una de las funciones del lenguaje. La consecuencia inmediata es que el lenguaje es acción y, como no existe lenguaje sin pensamiento, éste se halla ligado a la acción.

Heidegger afirmó "soy lo que digo". Se podría añadir que somos lo que hacemos.

Se parte del origen de la palabra drama: $\delta \rho \alpha \mu \alpha$, de $\delta \rho \alpha \omega=$ hacer. Decir es una acción verbal. Los gestos encierran la adecuación de elementos faciales y los ademanes precisan de la colocación de nuestros miembros: ambos son parte de los movimientos expresivos de los actores. Una expresión musical se resuelve mediante acordes, que son combinaciones armónicas; las sinfonías o los conciertos tienen movimientos; en la puesta en escena los personajes se mueven para situarse, para presentar una postura, para hacer mutis; el movimiento en televisión se logra mediante el recorrido de un pincel electrónico. Todo se resuelve arbitrando actuaciones.

Los eventos son las acciones y los acontecimientos. Las primeras se consideran como provocadas por un agente animado; los segundos, causados por un factor ambiental o una colectividad anónima.

La acción se analiza al nivel de texto completo. Los elementos que la componen son: las situaciones, su fragmentación, la conexión entre ellas, las transformaciones, el esquema narrativo y relaciones, configuración de las situaciones, y los componentes de la acción.

La quinta unidad básica es la imagen visual y auditiva.

Las imágenes del teledrama reproducen un objeto perceptivo, pero excluyen del mundo que ve ya que ni siquiera participa en su constitución. En la función teatral se elige el punto de vista, el encuadre y el plano, y se privilegia la figura, elementos que en televisión vienen impuestos. En el teledrama se percibe la imagen empobrecida con relación a lo representado.

Entran en la constitución del plano de la expresión visual los elementos geométricos elementales (punto, línea y plano), el cromatismo, la textura, la mayor o menor presencia de luz, el contraste, la dimensión, la proporción, el movimiento, y sus relaciones compositivas.

Sin más dilación se estructura el modelo de análisis de las cinco unidades básicas del teledrama.

\footnotetext{
${ }^{3}$ Se llega con los sentidos.
} 


\section{1.- Ficha identificativa}

Tomando la fuente primaria (cinta o DVD) se prepara la ficha identificativa del teledrama, procediendo a la significación contextual del mismo (condiciones históricas, políticas, culturales, sociales, etc.) y describiendo -en síntesis- el argumento (tabla 2).

\section{Tabla 2}

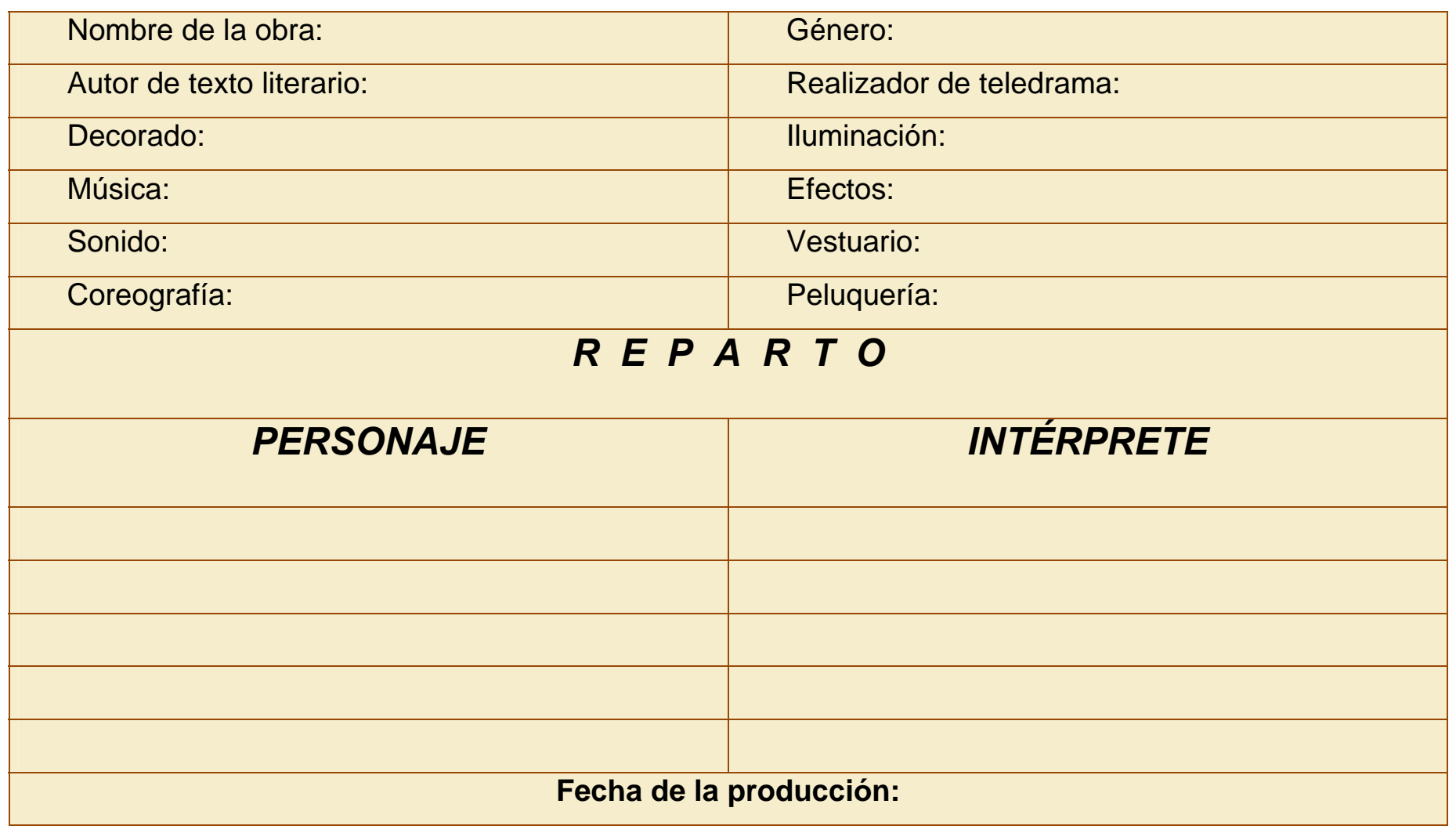

\section{Doble lectura del texto}

Es necesario descomponer el texto teatral en segmentos fácilmente identificables (generalmente escenas), señalándolos con claridad en la copia de trabajo. Si no se dispone del guión literario del teledrama, se revisa el texto dialógico en su fuente primaria, corrigiendo la copia del drama originario. Así mismo se revisa el para-texto. A este inicio del proceso se le ha llamado doble lectura del texto. 
Es conveniente materializar en una tabla los personajes que intervienen en cada uno de los segmentos.

La valoración de las diferencias entre la transducción a guión literario del teledrama y el texto literario teatral originario se realiza, fundamentalmente, al nivel del texto dialógico. En este apartado es común suprimir y no agregar líneas y réplicas en la adaptación, con objeto de obtener la duración aconsejable para el espacio televisivo. La puesta en escena y en imagen del teledrama es específica del medio televisivo y tiene, por tanto, sus requerimientos particulares. No obstante, suele responder al para-texto de la obra de teatro, salvo en lo referente a movimientos internos de los personajes, supeditados a la situación de las cámaras, encuadres, etc.

\section{3.- Personajes}

El análisis de este apartado se estructura en los siguientes sistemas: texto pronunciado (inventario, características, signos supra-textuales, prosodia, modelo, orden diegético, modalidades argumentativas, sub-texto), expresión corporal, proxémica, apariencia exterior del comediante, visión lingüística, relaciones e importancia.

El primer criterio para el estudio de los personajes es su presencia o ausencia. En casi todos los casos, los personajes in absentia posen una gran importancia. Recuérdense casos como PEPE EL ROMANO, de La casa de Bernarda Alba o MAURICIO de Madrugada.

\section{1.- Texto pronunciado}

El análisis de este sistema se inicia, en el plano elemental, con el inventario de las intervenciones de los distintos personajes, indicando su participación en cada segmento. El número de escenas en que toma parte cada uno es un dato orientativo para calibrar su importancia. Se utilizará, por comodidad, la fuente secundaria.

Completados los segmentos elementales, cuadros y actos, se confecciona una tabla resumen por personajes y unidades intermedias y mayores (actos y plano textual).

Luego se señalan, por personajes, el número de réplicas y el de líneas o versos en cada segmento. Lo obtenido en el plano elemental se integra en el plano intermedio -en la misma tablasumando, por actos, las líneas o versos y se completan los datos a nivel del plano textual. 
El número de monólogos, soliloquios, apartes y apelaciones ${ }^{4}$ en cada segmento elemental y a nivel de los planos superiores es un dato que, como las réplicas, resulta eficaz en la evaluación de la importancia del personaje.

Dentro de los planos intermedio y textual se establecen las relaciones de coherencia o incoherencia entre réplicas. ${ }^{5}$

Otro dato fundamental es el de las características del lenguaje verbal, por personajes, comenzando por las cualidades primarias (intensidad, tono y timbre) en los tres planos de coherencia semántica. La intensidad se valora como alta, normal o baja; el tono es agudo, medio o grave y el timbre, de voz clara, apagada o profunda.

Los rasgos del lenguaje verbal se completan con las características gramaticales, sólo a nivel del plano textual. Son la corrección (depurada, normal o descuidada) y el léxico (cuidado, normal y vulgar)

Los signos supra-textuales o elementos verbales-signo realizan, dentro de las réplicas del texto dialogado, funciones de para-texto y, principalmente, son:

a) Caracterización de los personajes (status social, edad, cualidad psicológica, nivel profesional y cultural, origen, etc.).

b) Tiempo.

c) Decorado verbal (en el espacio o en la escenografía)

d) Acción verbal (descripción de acciones ocultas a la vista).

En el plano del sujeto, las cualidades primarias, las características gramaticales y los elementos prosódicos se pueden convertir en elementos verbales-signo de la edad, sexo, estado de ánimo (avergonzado, derrotado, alegre, humillado, culpable, optimista, deprimido, admirado, etc.), sentimiento, origen familiar, recursos económicos, extracción social, nivel cultural, etc.

El análisis prosódico suele circunscribirse al estudio de los personajes principales en los tres planos de coherencia semántica.

En cuanto a la entonación, se valoran, sobre todo, las oraciones interrogativas e imperativas, que son las que más se evidencian en el texto audiovisual.

\footnotetext{
${ }^{4}$ Cuando el comediante se sale de la ficción y se dirige directamente al público.

${ }^{5}$ En la mayoría de los casos la relación es coherente.
} 
En el acento principal, la dicción, el ritmo y la originalidad se han tenido en cuenta los tipos indicados en la tabla 3 , y se ha dado la importancia que corresponde a las pausas, los silencios y la acentuación tónica de las palabras.

Tabla 3

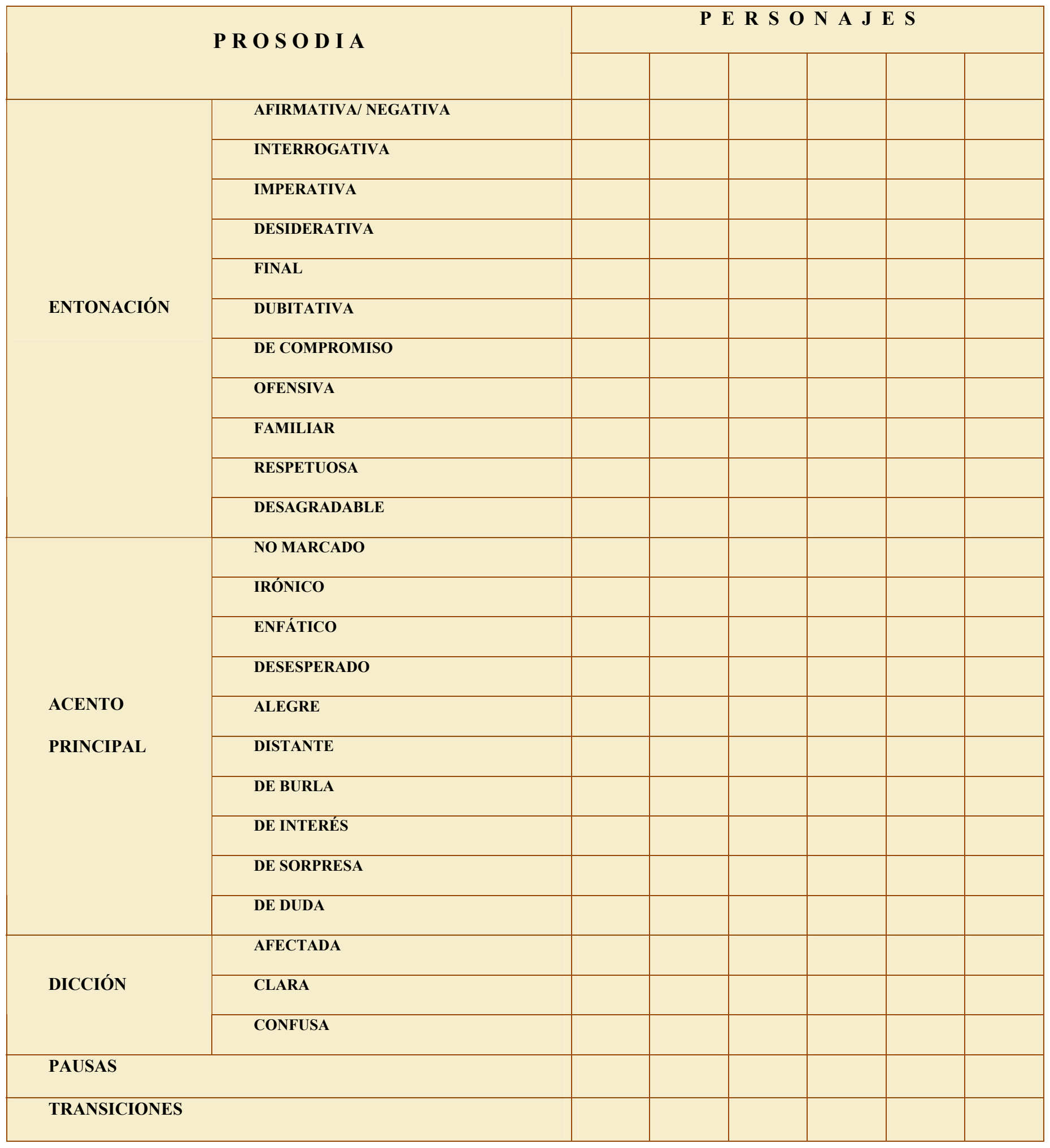




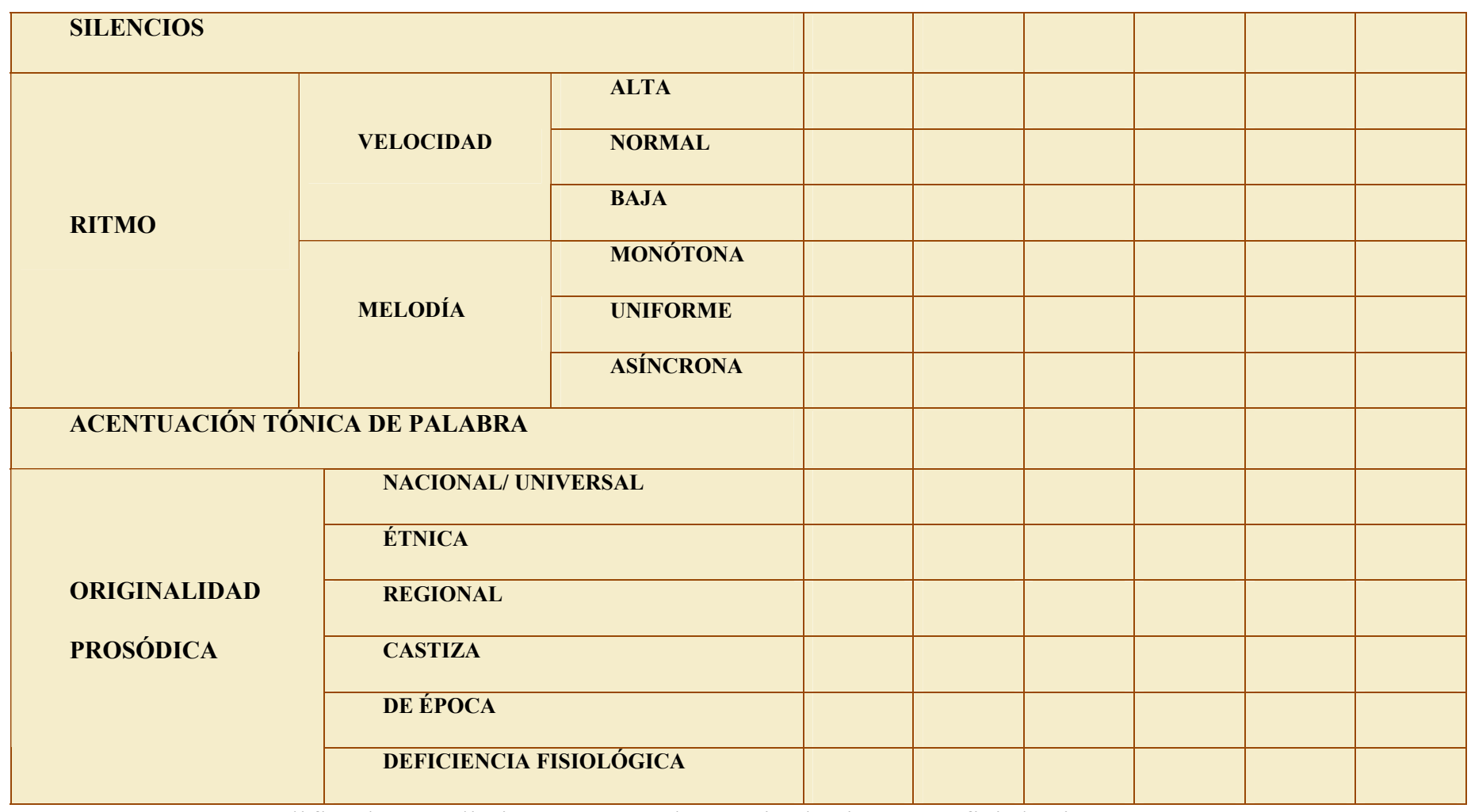

Los modificadores distinguen estados psicológicos o fisiológicos. Son calificadores: respiración, cuchicheo, nasalidad, etc.; diferenciadores: risa, llanto, grito, tos, bostezo, etc.; y alternantes: intención de hablar o de interrumpir, interjecciones vocales no articuladas (pst, tsch, etc.) y otros.

En este estudio se prescinde de otros análisis que profundizan en el aspecto lingüístico de la obra literaria y se limita a la puesta en imagen televisiva de la obra originaria.

La sumisión, o no, al modelo aristotélico, la relación entre sus tres partes y los tipos de estructuras para unir los contenidos del discurso muestran otros puntos a señalar (Tabla 4).

\section{Tabla 4}

MODELO ARISTOTÉLICO (planteamiento, nudo, desenlace) :

\section{MODALIDADES ARGUMENTATIVAS}

\begin{tabular}{l|l|l|l|l|l|l|}
\hline AL CASUAL & CENTRADA & DISPERSA & COMPLETA & INCOMPLETA ĹGICA & CF \\
\hline & & & & & & \\
\hline
\end{tabular}


El sub-texto ocupa un lugar preferente en este modelo de análisis. Significa el mundo interior del personaje, lo sobreentendido, las razones ocultas al exterior y presentes en su interior, aquello que no se dice abiertamente, pero que se quiere decir, lo existente aunque encubierto (Tabla $5)$.

Tabla 5

\begin{tabular}{|l|l|l|l|}
\hline \multirow{2}{*}{ ESCENA } & \multicolumn{2}{|c|}{ RÉ P L ICA S } & \multirow{2}{*}{ SUB-TEXTO } \\
\cline { 2 - 4 } & PERSONAJE & TEXTO & \\
\hline & & & \\
\hline & & & \\
\hline & & & \\
\hline
\end{tabular}

\subsection{Expresión corporal}

Se estudian gestos, ademanes, posturas, movimientos expresivos y una aproximación a la proxémica. Los tres primeros se analizan en los planos del objeto, del sujeto e inter-subjetivo. En el teledrama se entienden como intencionados. En el plano del objeto la cantidad de elementos agregados al habla suele ser muy superior al resto. Se identifican pormenorizadamente los correspondientes al plano del sujeto. Los movimientos escénicos internos se señalan en la puesta en imagen.

En cuanto a las posturas, puede ser interesante -aunque no es frecuente- significar la posición final, la locomoción (movimiento para obtenerla) y la velocidad para conseguirla. La postura nos ayuda en la caracterización del personaje y es indicativa de la predisposición o no para la acción (Tabla 6).

Tabla 6

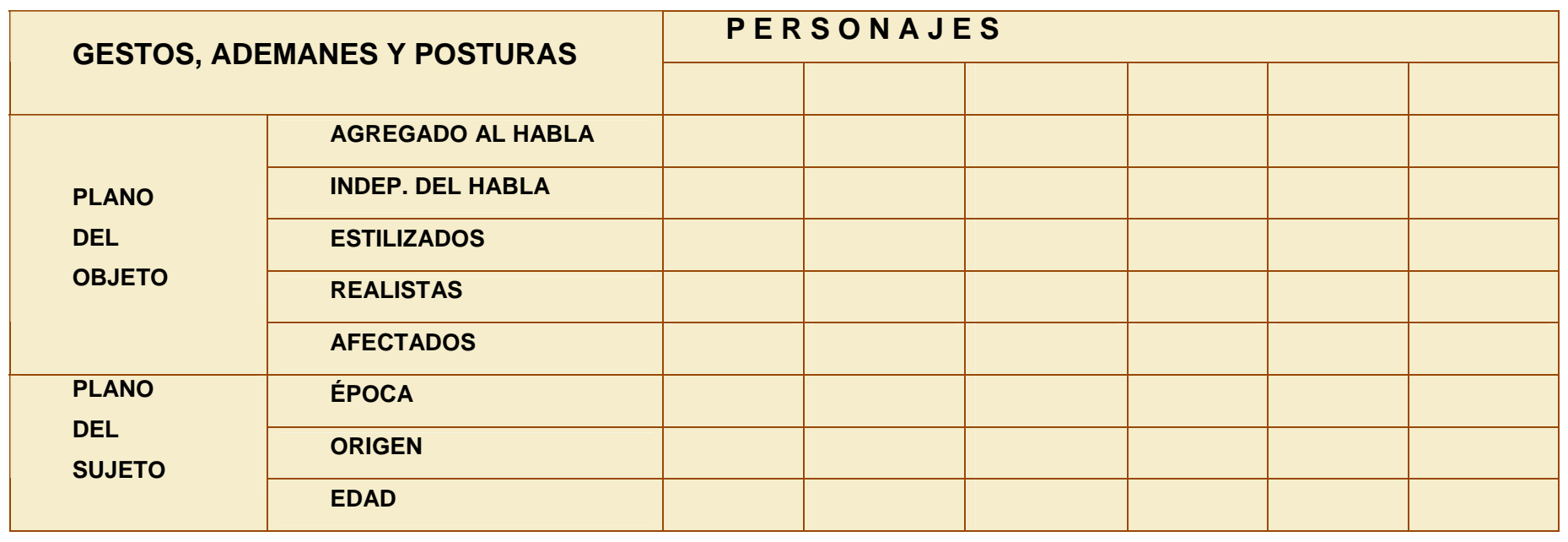




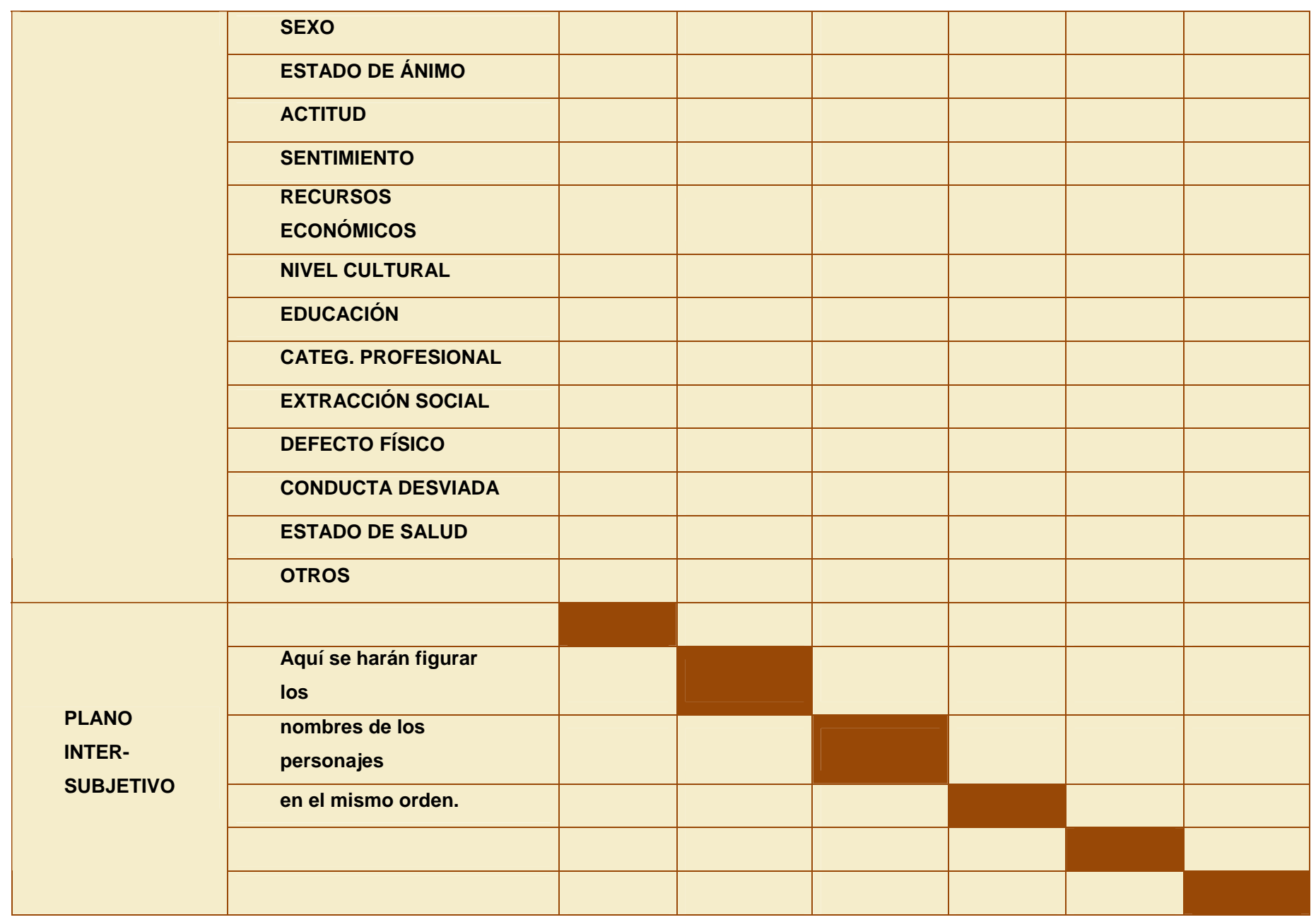

Los diferentes movimientos expresivos: $\operatorname{prosbólicos}^{6}, \operatorname{simpatéticos}^{7}, \operatorname{simbólicos}^{8} \mathrm{y}$ metafóricos ${ }^{9}$, se valoran en intensidad, extensión y velocidad. La intensidad es alta o tensa, media y baja; la extensión corta, normal y ancha o ensanchada; y la velocidad lenta, normal y rápida. En el teledrama se considera normal la intensidad baja, la extensión corta y la velocidad lenta.

\footnotetext{
${ }^{6}$ Enfocan el sentido para percibir el mensaje.

${ }^{7}$ Movimiento de todo el cuerpo para expresar un sentimiento.

${ }^{8}$ Demostración de la fantasía. Por ejemplo, una mirada perdida.

${ }^{9}$ Movimientos inteligentes. Por ejemplo, una mirada expresiva.
} 


\subsection{Proxémica}

Se procede después al análisis de la utilización del espacio por los personajes en la puesta en escena. Es el estudio proxémico. En el teledrama es aproximada.

La proxémica estudia las relaciones de comunicación a través de las distancias entre los personajes entre sí, entre los personajes y los objetos, y el lugar que ocupan los comediantes en el espacio dramático. A través de estas distancias el espacio comunica. Nuestra visión, como espectadores de este juego del espacio es mucho más efectiva en teatro que en televisión.

Se trata de determinar las distancias íntimas, personales, sociales o públicas.

Las personas tienden a situarse más próximas a quienes simpatizan; la proximidad depende también del carácter de los encuentros, de que éstos sean muy formales o amistosos e íntimos cuando llegan incluso a tocarse (Tabla 7).

Umberto Eco (1994; 329-330) mantiene vigentes las distancias citadas por Hall. Las distancias íntimas se mueven entre los 15 y $20 \mathrm{~cm}$. Con la posibilidad del contacto físico; las personales, entre $0.75 \mathrm{y}$ $1.25 \mathrm{~m}$; las sociales se encuentran entre 2 y $3.5 \mathrm{~m}$. y las públicas por encima de este valor.

\section{Tabla 7}

\begin{tabular}{|c|c|c|c|c|c|c|c|c|c|c|}
\hline \multicolumn{3}{|c|}{ ACTO PRIMERO } & \multicolumn{4}{|c|}{ ACTO SEGUNDO } & \multicolumn{4}{|c|}{ ACTO TERCERO } \\
\hline PE. & so. & PÚ. & IN. & PE. & so. & PÚ. & IN. & PE. & so. & PÚ. \\
\hline & & & & & & & & & & \\
\hline & & & & & & & & & & \\
\hline & & & & & & & & & & \\
\hline & & & & & & & & & & \\
\hline & & & & & & & & & & \\
\hline & & & & & & & & & & \\
\hline & & & & & & & & & & \\
\hline & & & & & & & & & & \\
\hline & & & & & & & & & & \\
\hline & & & & & & & & & & \\
\hline & & & & & & & & & & \\
\hline
\end{tabular}




\begin{tabular}{|l|l|l|l|l|l|l|l|l|l|l|}
\hline & & & & & & & & & \\
\hline & & & & & & & & & \\
\hline & & & & & & & & \\
\hline & & & & & & & & & \\
\hline & & & & & & & & & \\
\hline & & & & & & & & & & \\
\hline
\end{tabular}

\subsection{Apariencia exterior del comediante}

Se analiza, habitualmente, a nivel de plano textual.

El análisis, en el plano textual, se comprende el aspecto físico del actor (normal, delgado o grueso), su estatura (baja, media o alta) y su complexión (débil, normal o fuerte). También se reseñan los defectos físicos.

En lo referente a vestuario, peluquería, y utilería del comediante es conveniente su descripción por personajes.

Para las características de todos los elementos, se propone la tabla 8 para cada uno de los actos y su integración en otra para el teledrama completo.

Tabla 8

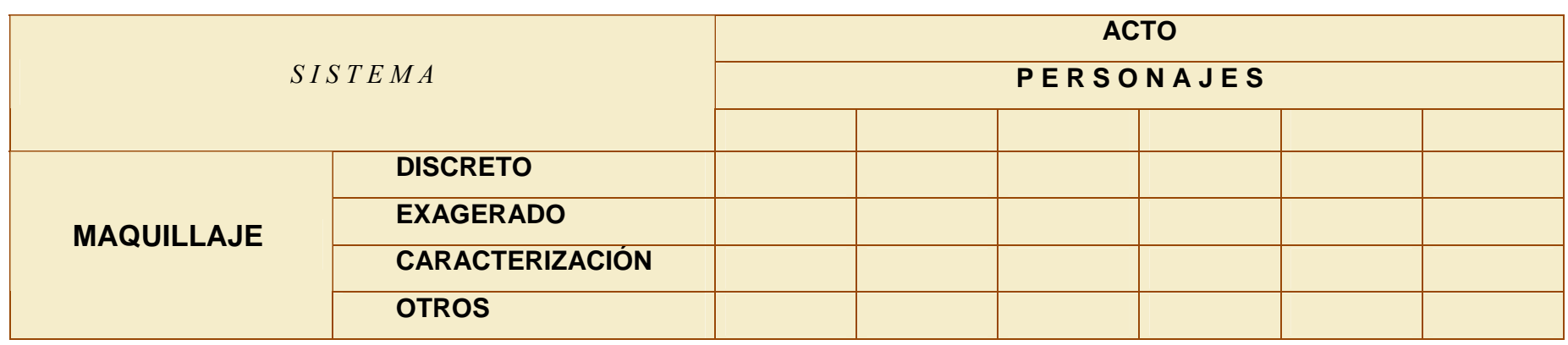




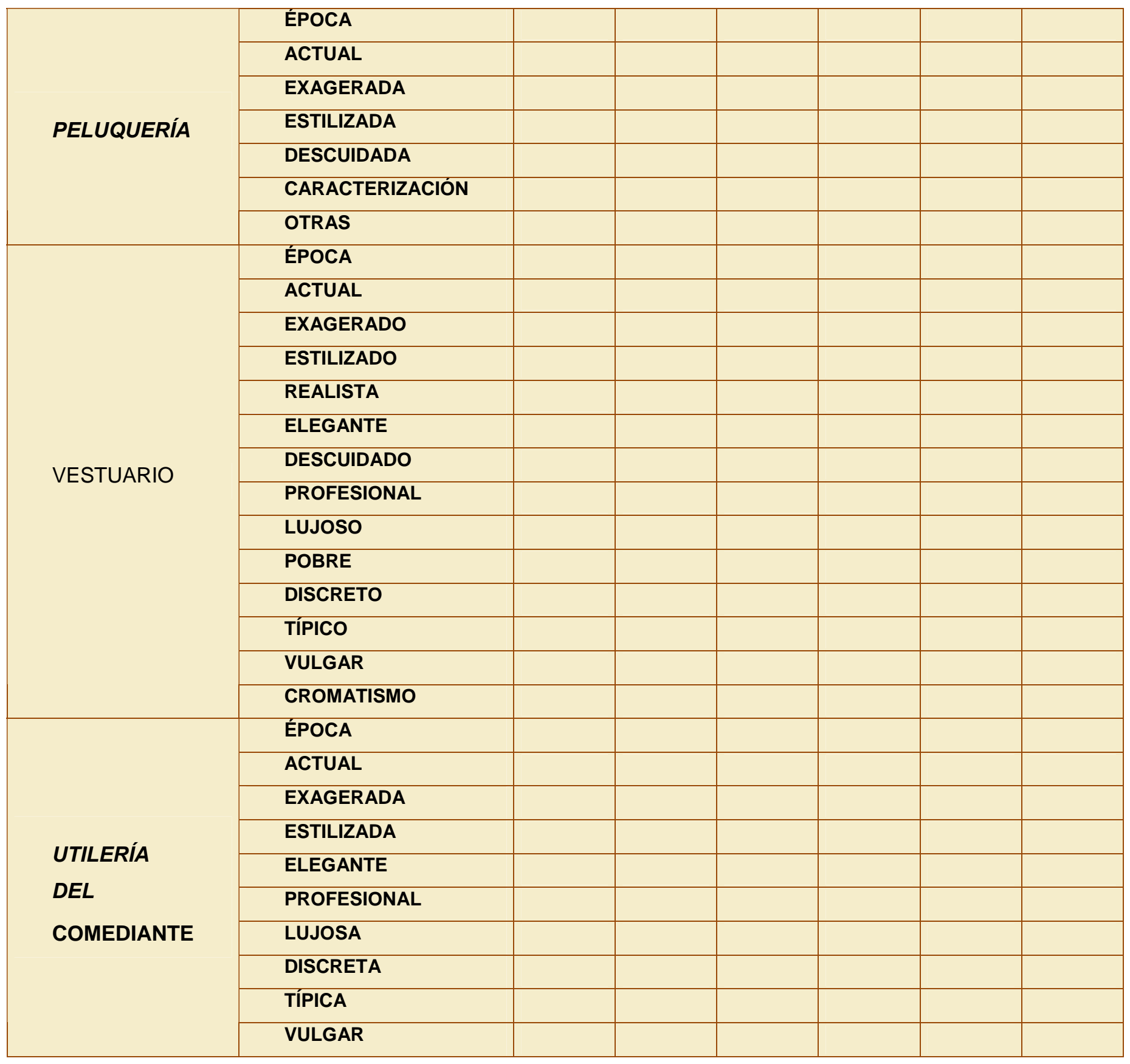

\subsection{Visión lingüística}

El personaje es una unidad sintáctica y un lexema. Se presenta como metonimia ${ }^{10}$ o sinécdoque $^{11}$ (por ejemplo, el loco bufón de El rey Lear es metonimia del rey en su locura), como metáfora ${ }^{12}$

\footnotetext{
${ }^{10}$ Sentido parecido de dos cosas diferentes.

${ }^{11}$ Sentido parecido de dos cosas iguales.

${ }^{12}$ Empleo de la expresión en un sentido diferente en parte.
} 
(FEDRA es metáfora de la conjunción del deseo y de su represión; en teledramas como El tintero, de Carlos Muñiz, hay gran cantidad de personajes metafóricos: CROCK es metáfora de la libertad, FRANK de la crueldad y los hay de la falsedad, del poder, de la inmoralidad, etc.), o como oxímoron $^{13}$ (CORDELIA, en El rey Lear, aparece como hija, siendo metáfora de vida, fecundidad y futuro, y como muda, siendo metáfora de muerte)

Como conjunto semiótico, cada personaje tiene una serie de rasgos distintivos: nombre, sexo, edad, características físicas del actor o envergadura, su aspecto externo (maquillaje, peinado, indumentaria), máscaras, hipérboles (por ejemplo, la BERNARDA interpretada por Ismael Merlo, el DON JUAN de Ana Mariscal o el HAMLET de Nuria Espert), etc.

El personaje puede venir codificado (galán, gracioso, etc.), conocido por su historia o su leyenda, con identidad prestada (aunque conocida por el telespectador), problemático. Es importante destacar si es definido antes o después de su primera aparición en escena, y si se trata de personaje in praesentia o in absentia.

Además, será un personaje estático (sin evolución en el teledrama) o dinámico (en caso contrario).También puede ser lineal o contrastado con respecto a los demás. Será un personaje encarnado si representa fenómenos abstractos (virtud, belleza, etc.)

Se indican las características de la interpretación de cada personaje (histriónica, austera, justa, fría, intensa, hiperbólica).

\subsection{Relaciones}

El personaje se relaciona con el autor del texto literario originario. Si éste, en su texto, le ha dejado indefinido, se trata de un personaje plano. Por el contrario, si ha proporcionado abundante información (tanto en didascalias y acotaciones, como en las réplicas de otros personajes o en la denominada auto-caracterización) le calificamos como figura redonda o personaje con relieve. Esta información siempre puede ser explícita o implícita. El código para transmitir estos datos puede ser verbal o extra-verbal. En el primer caso, en texto pronunciado; en el segundo, por signos noverbales.

\footnotetext{
${ }^{13}$ Coordinación de dos antónimos.
} 
Es preciso establecer las diferentes relaciones de correspondencia o contraste, formales (de oposición, apoyo o indiferencia) y las interacciones entre personajes.

La interacción puede ser positiva (beneficiosa para el personaje), negativa (perjudicial) o neutra (no hay interacción) y conducirá al imprescindible conflicto.

Es común acudir a las propuestas por Greimas (1987) en su modelo actancial. El remitente guía al sujeto que busca un objeto en interés del destinatario (concreto o abstracto). En esta búsqueda, el sujeto y/o el objeto (dependiendo de donde suceda el conflicto) tienen sus ayudantes y sus oponentes (Tabla 9).

\section{Tabla 9}

\begin{tabular}{|c|c|c|c|c|c|}
\hline \multicolumn{2}{|c|}{ REMITENTE } & \multicolumn{3}{c|}{ DESTINATARIO } \\
\hline \multicolumn{2}{|c|}{ OPONENTES } & SUJETO & OBJ & AYUDANTES & OPONENTES \\
\hline AYUDANTES & ETO & & \\
\hline
\end{tabular}

Los modelos actanciales por fragmentos se unifican considerando unidades mayores hasta llegar al plano textual por cada sujeto pertinente.

Estas relaciones, su forma y las interacciones, junto con el modelo actancial resultan útiles para la caracterización del personaje y contribuyen muy eficazmente a la determinación de la importancia de cada uno y a la evolución del drama.

Las relaciones entre los distintos elementos del sistema de los personajes suelen ser coherentes y así se hace notar.

\subsection{Importancia de los personajes}

Para fijar la importancia de los personajes se cuenta con los datos necesarios, tanto desde el punto de vista cuantitativo como cualitativo.

Cuantitativamente se estudia el número de escenas en que el sujeto está presente (no sólo en pantalla), el texto pronunciado (el número de réplicas y el de líneas o versos), los cambios de vestuario, la copresencia de otros personajes, y el tiempo de permanencia en escena (no sólo en 
pantalla). Este último puede ser fundamental (por ejemplo, el caso de ANITA, en Las cartas boca abajo, de Buero Vallejo, que no habla), al relacionar el número de escenas y el de réplicas con su medida en líneas o versos.

Desde el punto de vista cualitativo, se tendrán en cuenta la importancia del contenido de las réplicas, la existencia de monólogos o soliloquios, el posible idiolecto, la expresión oral y la gestual, la manera de andar y las posturas, los movimientos, la auto-calificación y la calificación por los demás, el status social y el nivel cultural. Se analizan las razones por las que el personaje dialoga con uno y no lo hace con otros.

Para la importancia de las réplicas se propone su evaluación en muy alta, alta, media-alta, media o baja; la expresión oral será buena, enfática, deficiente; la expresión gestual, normal, afectada, grosera.

La manera de andar, las posturas y los movimientos pueden ser elegantes, normales, vulgares, toscos, etc. En cuanto a los últimos, interesa también la aparición de los que se han considerado simbólicos o metafóricos.

Todas las características apuntadas hasta el momento nos permitirán realizar una calificación exhaustiva de los personajes.

\section{Espacio}

Se inicia con la descripción detallada de los elementos del sistema (decorado, mobiliario y utilería ambiente) y sus características principales: actual o de época, estilizado, exagerado o realista, elegante o vulgar, lujoso, clase media o pobre, típico, etc.

La espacialización refiere la deixis espacial, que sitúa lo ostensible, es decir, si se trata de espacio interior o exterior, y la identificación del espacio, que lo presenta en dimensiones menores (salón, dormitorio, cocina, etc.), reducidas (piso, casa, palacio, castillo, parque, etc.) y grandes (país, comunidad, ciudad, pueblo, etc.). La iconización expresa la significación (histórica, política, social, etc.)

Se concretan las características de la iluminación en los espacios dramático y escenográfico y al nivel que -según la obra- sea pertinente (Tabla 10). 
Tabla 10

\begin{tabular}{|c|c|c|c|c|c|c|}
\hline \multirow{3}{*}{ АСТО } & \multirow{3}{*}{ CUADRO } & \multirow{3}{*}{ ESCENAS } & \multicolumn{4}{|c|}{ I LUM I N A C I ÓN } \\
\hline & & & \multicolumn{2}{|c|}{ AMBIENTACIÓN } & \multicolumn{2}{|c|}{ PUNTOS DE LUZ } \\
\hline & & & TIPO & sí & CLASE & CANT. \\
\hline & & & EXTERIOR & & $\begin{array}{l}\text { LÁMPARA } \\
\text { DE } \\
\text { TECHO }\end{array}$ & \\
\hline & & & INTERIOR & & $\begin{array}{l}\text { LÁMPARA } \\
\text { DE PIE }\end{array}$ & \\
\hline & & & DÍA & & $\begin{array}{l}\text { LÁMP. } \\
\text { SOBREM } \\
\text { ESA }\end{array}$ & \\
\hline & & & NOCHE & & APLIQUE & \\
\hline & & & AMANECER & & FLEXO & \\
\hline & & & CREPÚSCULO & & VELAS & \\
\hline & & & IRREAL & & OTRAS & \\
\hline
\end{tabular}

Dentro de la utilería ambiente pueden adquirir especial relieve los objetos-signo. Hay teledramas en que este elemento cobra una extraordinaria importancia.

Sus características operativas son: la situación, que determina si se trata de un elemento físico, manteniéndose dentro del espacio visible, o de un componente lingüístico o verbal, fuera de dicho espacio; la fabricación aparente, que define su procedencia artesanal o industrial; su estado de conservación, es decir si parece nuevo o usado.

También su utilización, aclarando si, en su aplicación, es un objeto utilitario, profesional o de adorno; si parece lujoso o no; si su pertenencia es a la utilería -ambiente o de personaje- al decorado, al mobiliario o a la iluminación; y si ha sufrido, intencionadamente, un deterioro evidente en el desarrollo del teledrama.

Después, se analizan sus rasgos concretos: en cuanto al cromatismo, los matices dominantes y la temperatura. Respecto al estilo se señala si es de época, actual indeterminado, u otro; se valora el status social y el nivel cultural de los personajes, siempre que el objeto-signo los subraye.

Se señala la apariencia de sus rasgos distintivos (madera, plástico, tejido, metal, etc.) y, de acuerdo con ella, los rasgos pertinentes (riqueza, bienestar, elegancia, etc.) y los contextuales. 


\subsection{Tipología de los espacios}

La segmentación considerada en el plano elemental se integra en un espacio único o dividido en módulos, tanto al nivel de cuadros como de actos. Si es modular, es preciso indicar las modalidades de conexión entre ellos (yuxtaposición, inclusión). Hay que tener en cuenta si es en anchura o en altura.

Existe la posibilidad de espacios "prótesis" o agregados (intra o extra-diegéticos) o de espacios aludidos. También pueden estar configurados por la música o por la luz. En el caso de espacio aludido -además del decorado verbal ya citado en los elementos verbales, dentro del plano elemental- puede tratarse de espacio en off (que puede tener gran importancia, como en La tejedora de sueños, de Buero Vallejo) o de espacio distante (del pasado o de los sueños).

\subsection{Dinámica de los espacios}

En la escenografía del teledrama es necesario adaptar la forma teatral, captando la acción desde los más diversos puntos de vista. Esto es una razón más para abandonar definitivamente las retransmisiones teatrales como tales. Los decorados, los muebles, la utilería y la colocación de los personajes se realizan teniendo en cuenta el necesario movimiento de las cámaras, que se posibilita, en gran medida, gracias a los elementos de decorado y atrezzo móviles. Puede romperse el decorado, aprovechar huecos y "violar" puertas y ventanas.

Los espacios pueden ser variables, si cambia decorado, mobiliario o utilería sobre un mismo espacio escénico (Por ejemplo: La Fundación de Buero Vallejo); cambiantes si se trata de varios espacios no simultáneos (Casa de muñecas, de Ibsen); múltiples si se trata de espacios simultáneos (El grillo de Carlos Muñiz), o fijos si se mantiene constante a lo largo de toda la función o grabación (Hay que deshacer la casa, de Sebastián Junyent).

\subsection{Elementos de los espacios}

De los componentes que conforman el espacio - salvo la iluminación- hay que definir los elementos constituyentes y los caracterizantes. Los primeros son los formantes del espacio dramático 
(decorados, mobiliario y utilería de ambiente) y serán esenciales o no; los segundos se refieren a su influencia en la caracterización del teledrama.

Los elementos constituyentes pueden ser centrales si son indispensables en la escena o unidad segmentada (situación, cuadro, acto), o periféricos si podemos prescindir de ellos. Los elementos caracterizantes son extensos si caracterizan el drama, e intensos si no es así.

También es necesario señalar si tanto los decorados como el mobiliario y la utilería de ambiente funcionan principalmente como utilitarios, referenciales, cotidianos, históricos, simbólicos o de lo imaginario.

\subsection{Estilística de los espacios}

El tipo de arquitectura definirá si es actual, de época, futurista o indeterminada, si es rural o urbana. La unidad nos situará en la deixis menor, es decir, si se trata de salón, cocina, dormitorio, jardín, etc. En cuanto a los componentes se anotarán los principales, dentro de cada elemento. El ambiente será neutro, estilizado o concretado.

\subsection{Transformación del espacio}

Es fundamental que se expresen, al nivel del plano textual, los cambios experimentados por cada unidad a lo largo del teledrama.

La transformación se percibe como cambio. Si afecta al sistema espacio, lo podrá hacer en cualquiera de sus elementos: decorado, mobiliario, utilería o iluminación. El ejemplo más característico en nuestro teatro contemporáneo lo tenemos en La Fundación, de Antonio Buero Vallejo, producido en 1977. En este teledrama sufren transformación los cuatro elementos.

\subsection{Relaciones en el sistema}

Las relaciones entre las distintas unidades del espacio suelen ser coherentes y así se hace notar. 


\section{Tiempo}

La temporalidad resume las características del tiempo. En su figurativización aparecen la época en la que se encuadra el teledrama, la estación, el tiempo de reloj (amanecer, día, mañana, tarde, crepúsculo o noche); en su iconización, si se trata de pasado, presente o futuro, y las relaciones que puede tener el tiempo con el clima y con el sentido de la diégesis.

La duración del teledrama, primero por segmentos elementales (generalmente escenas) y luego al nivel de unidades medias y totales (actos y obra completa) es un dato fundamental en el análisis. Esta cuantificación se refleja en las tablas 11 y 12.

\section{Tabla 11}

\begin{tabular}{|c|c|c|c|c|c|c|c|}
\hline \multicolumn{8}{|c|}{ A C T O } \\
\hline UNIDAD & \multicolumn{4}{|c|}{ D U R A C I Ó N P O R } & \multicolumn{3}{|c|}{ E S C E N A S } \\
\hline ESCENA & 1 & 2 & 3 & 4 & 5 & 6 & 7 \\
\hline TIEMPO & & & & & & & \\
\hline ESCENA & 8 & 9 & 10 & 11 & 12 & 13 & 14 \\
\hline TIEMPO & & & & & & & \\
\hline ESCENA & 15 & 16 & 17 & 18 & 19 & & \\
\hline TIEMPO & & & & & & & \\
\hline
\end{tabular}

Tabla 12

\section{TOTAL TIEMPO}

REPRESENTADO

\begin{tabular}{c|c|c|c|c|c|c|}
\multirow{2}{*}{$\begin{array}{c}\text { UNIDADES } \\
\text { DRAMÁTICAS } \\
\text { MAYORES }\end{array}$} & PRIMERA & \multicolumn{2}{|c|}{ BLOQUE PUBLIC. } & \multicolumn{2}{|c|}{ SEGUNDA } & \multicolumn{2}{|c|}{ TERC } \\
\cline { 3 - 3 } & PARTE & SPOTS & TIEMPO & PARTE & SPOTS TIEMPO \\
\hline
\end{tabular}


En los enunciados de estado, en la modalidad del /estar y ser/, la afirmación del /querer-estar y ser/, que representa lo deseable, nos lleva a la no afirmación /no querer-estar y ser/, que es lo indeseable. El /querer-no estar y no ser/, que indica lo repulsivo, nos conduce al contradictorio /no querer-no estar y no ser/, que admite lo no repulsivo. La afirmación /poder-estar y ser/ (posibilidad), nos transporta a la modalidad /no poder-estar y ser/ (imposibilidad), mientras que el /poder-no estar y no ser/ (contingencia) conduce al contradictorio /no poder-no estar y no ser/ (necesidad).

El acto o acción es una estructura que reúne performance y competencia. La primera se refiere a la acción realizada, es /hacer-ser/ o /hacer-estar/; la segunda incluye los conocimientos y habilidades requeridos para acometer la acción, es lo que /hace-ser/ o /hace-estar/. Courtés siguiendo a Greimas- distingue entre competencia semántica y modal. La primera es un procedimiento a seguir y no un /saber-hacer/. La competencia modal es la que hace posible que la competencia semántica pase a realización del programa narrativo. El guión literario de teledrama sería la competencia semántica de un realizador, y la habilidad de éste para ponerla en imagen televisiva sería la competencia modal.

Se descubren las manipulaciones del /hacer-hacer/ calificando a sus manipuladores a los niveles cognoscitivos de la seducción o de la provocación, y a los niveles pragmáticos de la tentación o de la intimidación. Determinamos la sanción y su retribución por saturación (si la situación final representa la conclusión previsible de acuerdo con el planteamiento inicial), inversión (en el caso de que la situación inicial se convierta, al final, en su opuesto), sustitución (cuando la situación inicial presenta alguna conexión con la final), suspensión (si la situación inicial no encuentra solución en la situación final realizada) o éxtasis (cuando la variación es prácticamente inexistente). Como consecuencia de este juicio aparece la retribución en forma de recompensa o de castigo.

Una vez establecida la acción es más sencilla la segmentación del teledrama en situaciones, la calificación de las mismas (aislada, agrupada o encadenada) y el orden (lineal o dividido, efectivo o aparente, lógico o cronológico).Se puede establecer la conexión ${ }^{15}$ y la consecuente relación entre

15 Narrativa (dos situaciones mantienen una relación temporal), deductiva (una situación se deduce a partir de otra precedente), motivada (se realiza mediante cadenas de motivaciones, abductiva de tipo causal (se propone una situación como efecto de otra, sin mediación de una voluntad consciente), abductiva de tipo funcional (una situación producida por un sujeto intencionalmente, se propone como funcional al verificarse otra), conceptual o lógica (entre 
las mismas o entre grupos de ellas (de dependencia, independencia e interdependencia). Dos situaciones tienen una relación de dependencia (siempre de una con la precedente) si no pueden cambiar de lugar; serán independientes si pueden hacerlo, e interdependientes si una se relaciona con la precedente y ésta con la siguiente. Serán coherentes las situaciones entre las que existan relaciones de dependencia o de interdependencia.

Inventariamos, en los enunciados de estado y del hacer, las distintas modalidades, las performances y competencias de la acción, las manipulaciones y las sanciones. Todo ello configura el esquema narrativo (Tablas 13, 14, 15 y 16).

Tabla 13

\begin{tabular}{|c|c|c|c|c|c|}
\hline \multicolumn{7}{|c|}{ M O D A L I D A D E S } \\
\hline \multicolumn{7}{|c|}{ ENUNCIADOS DE ESTADO } \\
(Querer, deber, poder y saber ser o estar) & \multicolumn{3}{|c|}{$\begin{array}{c}\text { ENUNCIADOS DEL HACER } \\
\text { (Querer, deber, poder y saber hacer) }\end{array}$} \\
\hline SIT. & & MODALIDAD & NÚ & PERSONAJE & MODALIDAD \\
NÚ & PERSONAJE & M. & & \\
\hline M. & & & & & \\
\hline & & & & & \\
\hline & & & & & \\
\hline
\end{tabular}

Tabla 14

\begin{tabular}{|c|c|c|}
\hline \multicolumn{2}{|c|}{ A C C I Ó N } \\
\hline \multicolumn{2}{|c|}{ PERFORMANCE } & COMPETENCIA \\
\hline DESEO & DESEO \\
\hline (/Querer-ser o estar) & $\begin{array}{c}\text { (IQuerer-hacer) } \\
\text { (/DESCRIPCIÓN }\end{array}$ \\
\hline OBLIGACIÓN & LIBERTAcer) \\
\hline (/Deber-ser o estar/) & (/Poder-hacer) & \\
\hline POSIBILIDAD & MODAL & \\
(/Poder-ser o estar) & (/Saber-hacer) \\
\hline CONOCIMIENTO & & \\
(/Saber-ser o estar) & & \\
\hline
\end{tabular}

\section{Tabla 15}

dos situaciones no se da una relación que haga posible que una de ellas dé lugar a la otra, ni que se produzcan recíprocamente, ni que provoquen una tercera situación, ni que sean gestadas por esta última). 


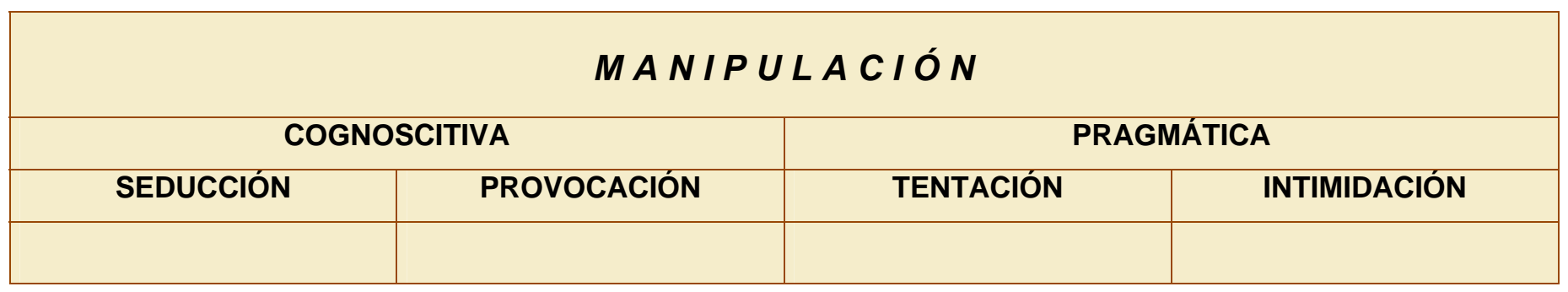

Tabla 16

\begin{tabular}{|l|c|c|c|c|}
\hline \multicolumn{5}{|c|}{ SANC IÓ N $\rightarrow$ R E T R I B U C I Ó N } \\
\hline SATURACIÓN & INVERSIÓN & SUSTITUCIÓN & SUSPENSIÓN & ÉXTASIS \\
\hline & & & & \\
\hline
\end{tabular}

La acción es un comportamiento que desemboca en situaciones. Se califica como voluntaria o involuntaria, consciente o inconsciente, individual o colectiva, transitiva o intransitiva (producirá o no consecuencias), singular o plural (originará efectos en una o más personas), única o repetitiva.

Sólo después de haber analizado la acción, descubierto su esquema narrativo y determinadas las situaciones, sus conexiones y sus relaciones, se podrá realizar el inventario de los conflictos e intrigas, que son los componentes finales de la diégesis.

La función del conflicto es relacionar por oposición a los personajes entre sí.

La intriga establece una cadena de conflictos en una sucesión de situaciones, a través de la relación a uno de ellos que forma su nudo. La intriga puede contener numerosos conflictos, y en un texto puede haber muchas intrigas. La intriga puede ser, pues, simple y compleja.

\section{Tratamiento de las imágenes}

Esta última parte del análisis comprende las fases de la puesta en escena audiovisual y la específica puesta en imagen televisiva.

Se inicia el estudio de la puesta en escena con el tipo de la misma. Se tratará de una puesta realista, naturalista, simbolista, expresionista, etc. Y será rígida, estilizada, efectista, hiperbólica, etc.

Pavis $(2000 ; 215)$ hace mención a la tipología de Lehmann y distingue tres puestas en escena:

1) Metafórica. Utiliza la escenificación como una metáfora del texto literario, comentándolo e ilustrándolo con medios escénicos.

2) Escenográfica. Se trata de una 'escritura' escénica autónoma. Usa la escenificación como lenguaje de pleno derecho. Sin estar supeditada al texto literario, puede tenerlo en cuenta. 
3) Del acontecimiento. Prescinde de manera absoluta del texto literario y crea su propio texto.

Los movimientos internos se evalúan cuantitativamente y el cromatismo y la supuesta textura, cualitativamente. Es conveniente hacerlo en los planos elemental, intermedio y textual. Como orientación se presentan los resultados en un modelo como la tabla 17:

\section{Tabla 17}

\section{DESCRIPCIÓN}

INCORPO-RARSE

\begin{tabular}{|c|c|c|c|c|c|c|}
\hline \multicolumn{3}{|c|}{ SENTARSE } & \multicolumn{4}{|c|}{ SOBRE SILLA } \\
\hline \multicolumn{2}{|c|}{ MUEBLE } & SUELO & \multicolumn{2}{|c|}{ SUBIRSE } & \multicolumn{2}{|c|}{ BAJARSE } \\
\hline NÚM & $\%$ & NÚM & NÚM & $\%$ & NÚM & $\%$ \\
\hline \multicolumn{6}{|c|}{ TEMPERATURA } & \\
\hline EÁLIDOS & \multicolumn{3}{|c|}{ FRÍOS } & \multicolumn{2}{|c|}{ TEMPLADOS } & \\
\hline
\end{tabular}

La música y los efectos se analizan en los planos intermedio y textual. Si fuera necesario se incluirían tantos bloques de tablas como elementos diferentes de descripciones. También aquí se sugiere la tabla 18 como modelo:

\section{Tabla 18}

\section{MÚSICA}

IPCIÓ

\begin{tabular}{|c|c|c|c|}
\hline \multicolumn{2}{|c|}{ FRAGMENTO } & \multicolumn{2}{c|}{ INTRA-DIEGÉTICA } \\
\hline NÚM & DURACIÓN & IN & O \\
\hline
\end{tabular}

\section{EFECTOS}

\begin{tabular}{c|c|c|}
\hline & \multicolumn{2}{|c|}{ EXTRA-DIEGÉTICA } \\
\hline OFF & \multicolumn{2}{|c|}{ EN DIRECTO } \\
\hline & & \multicolumn{1}{|c|}{ IDENTIF. } \\
IDENTIF. & IDENT. & PERSONAJ. \\
\hline & TIEMP. & \\
\hline & & \\
\hline
\end{tabular}

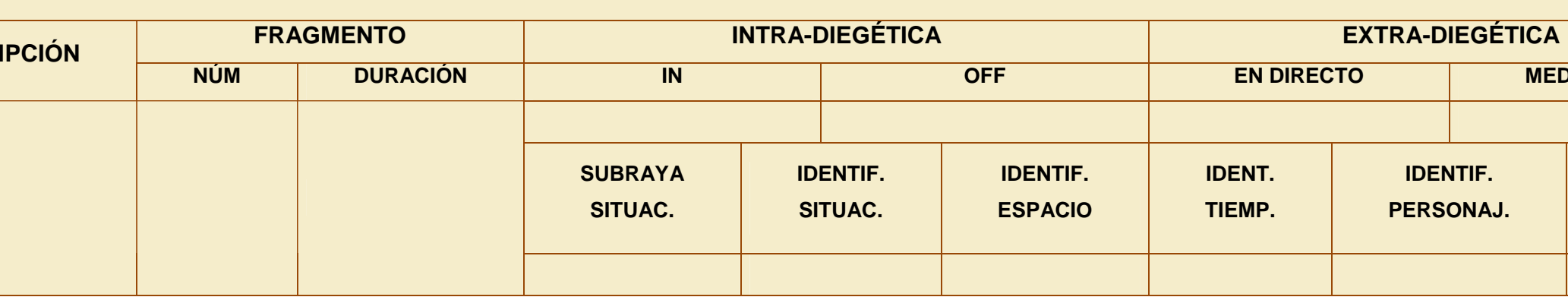

En cuanto a la puesta en imagen, se incluyen el inventario de planos, las características específicas de la misma en el plano de la expresión y los espacios bisagra. 


\begin{tabular}{|c|c|c|c|c|c|c|}
\hline \multirow{2}{*}{$\begin{array}{c}\text { PROFUNDIDAD } \\
\text { DE CAMPO }\end{array}$} & \multicolumn{3}{|c|}{ DILATADA } & \multicolumn{3}{c|}{ COMPRIMIDA } \\
\cline { 2 - 7 } & \multicolumn{3}{|c|}{ BLOQUES PUBLICITARIOS } & \multicolumn{2}{c|}{ CARETA FINAL } \\
\hline \multirow{2}{*}{$\begin{array}{c}\text { ESPACIOS } \\
\text { BISAGRA }\end{array}$} & CARETA INICIAL & \multicolumn{2}{|c|}{$\begin{array}{c}\text { NUM. } \\
\text { SPOTS }\end{array}$} & TIEMPO & DESCRIP. & TIEMPO \\
\cline { 2 - 7 } & & & & & & \\
\hline EFECRIP. & TIEMPO & BLOQ. & & & \\
\hline
\end{tabular}

\section{BIBLIOGRAFÍA}

CALABRESE, Omar, (1994): La era neobarroca. Edit. Cátedra, 2a edic., Madrid, trad. Anna Giordano.

COURTÉS, Joseph, (1997): Análisis semiótico del discurso. Edit. Gredos, $1^{\mathrm{a}}$ edic., Madrid, trad. Enrique Ballón Aguirre.

ECO, Umberto, (1994): La estructura ausente. Edit. Lumen, $5^{\text {a }}$ edic. Barcelona, trad. Francisco Serra Cantarell.

GREIMAS, Algirdas Julien, (1987): Semántica estructural. Edit. Gredos, $1^{a}$ edic., Madrid, trad. Alfredo de la Fuente.

KOWZAN, Tadeusz, (1992): Literatura y espectáculo. Edt. Taurus, $1^{\text {a }}$ edic. Madrid, trad. Manuel García Martínez.

PAVIS, Patrice, (2000): El análisis de los espectáculos. Edit. Paidós, $1^{\text {a }}$ edic., Barcelona, trad., Enrique Folch González.

UBERSFELD, Anne, (1997): La escuela del espectador. Edit. ADE, $1^{\text {a }}$ edic., Madrid, trad. Silvia Ramos. 